\title{
Evaluation of postural balance control in patients with multiple sclerosis - effect of different sensory conditions and arithmetic task execution. A pilot study
}

\author{
Ocena stabilności postawy u chorych na stwardnienie rozsiane - wpływ różnych warunków \\ sensorycznych oraz wykonywania zadania arytmetycznego. Doniesienie wstępne
}

\author{
Aleksandra Porosińska' , Krystyna Pierzchała², Marzena Mentel', Jacek Karpe ${ }^{3}$ \\ IKliniczny Oddział Neurologii, Samodzielny Publiczny Szpital Kliniczny nr 1, Śląski Uniwersytet Medyczny w Katowicach \\ 2Katedra i Klinika Neurologii, Wydział Lekarski z Oddziałem Lekarsko-Dentystycznym w Zabrzu, Ślạski Uniwersytet Medyczny w Katowicach \\ ${ }^{3}$ Katedra Anestezjologii i Intensywnej Terapii, Wydział Lekarski z Oddziałem Lekarsko-Dentystycznym w Zabrzu, Śląski Uniwersytet Medyczny w Katowicach
}

Neurologia i Neurochirurgia Polska 2010; 44, 1: 35-42

\begin{abstract}
Background and purpose: The purpose of this study was to investigate the effect of concomitant cognitive task execution and different sensory conditions on balance control in patients with multiple sclerosis (MS).

Material and methods: Thirty-two subjects with MS and 30 healthy age- and sex-matched control subjects were included in the study. Balance Performance Oriented Mobility Assessment was performed in all subjects. Their spontaneous sway characteristics while standing with different sensory conditions and during execution of a simple arithmetic task were analysed. Mean sway in the coronary and sagittal plane, as well as sway velocity, were measured.

Results: The values of all evaluated variables obtained in all tests were significantly higher in the MS group than in controls. In the MS group, more pronounced progression of changes in response to increased difficulty of the test was also observed. Analysis of risk of falls in MS revealed a significant increase of sway velocity and mean sway in the mediolateral and anteroposterior plane in the majority of tests.

Conclusions: Postural stability in patients with MS is significantly decreased in comparison with the control group in all evaluated conditions. Stability deficit is enhanced in
\end{abstract}

\section{Streszczenie}

Wstęp i cel pracy: Celem pracy było zbadanie wpływu wykonywania testu kognitywnego (zadanie arytmetyczne) oraz różnych warunków sensorycznych na kontrolę stabilności postawy u chorych na stwardnienie rozsiane (SR).

Materiał i metody: Badaniu poddano 32 chorych na SR oraz 30 zdrowych ochotników dobranych pod względem płci i wieku. W badaniu wykorzystano Kliniczny Test Oceny Równowagi i Chodu (Balance Performance Oriented Mobility Assessment) oraz ocenę charakterystyki swobodnych wychwiań postawy podczas stania w różnych warunkach sensorycznych i w trakcie równoczesnego wykonywania zadania arytmetycznego. Przeanalizowano średnią długość wychwiań postawy w płaszczyźnie czołowej i strzałkowej oraz prędkość wychwiań.

Wyniki: Wartości ocenianych zmiennych są znacząco większe w grupie chorych na SR niż w grupie kontrolnej. W grupie chorych obserwuje się również wyraźniejszą progresję zmian w odpowiedzi na zwiększenie trudności testu. Wzrost ryzyka upadków wykazuje istotną korelację ze zwiększaniem analizowanych parametrów posturogramu.

Wnioski: Stabilność postawy u chorych na SR jest znacząco gorsza w porównaniu z grupą kontrolną we wszystkich oce-

Correspondence address: Aleksandra Porosińska, Kliniczny Oddział Neurologii Samodzielnego Publicznego Szpitala Klinicznego nr 1 Śląskiego Uniwersytetu Medycznego w Katowicach, ul. 3-go Maja 13-15, 44-800 Zabrze, Polska, phone + 4832370 45 84, fax + 483227130 18, e-mail: alpia@interia.eu Received: 15.08.2009; accepted: 4.01.2010 
response to more difficult conditions of evaluation. Increased risk of falls is related to the increased postural sway velocity and length of mean sway; this association is most pronounced in the coronary plane.

Key words: multiple sclerosis, postural stability, arithmetic task, sensory condition.

\section{Introduction}

Multiple sclerosis (MS) is a chronic, progressive disease, characterized by inflammation, demyelination, axonal damage, and formation of sclerotic plaques within the brain and spinal cord. The progressive nature and involvement of different sites in the central nervous system (CNS) lead to variable presentation of neurological impairments [1].

Balance is the result of complex interactions between musculoskeletal and neuromuscular systems, including sensory components such as vision, the proprioceptive and vestibular system, motor and integrative parts [2-4]. All of them could be affected by MS: involvement of the visual system can be associated with blurred vision, diplopia and blindness [5]. Damage of the vestibular tracts by MS plaques causes vertigo and nystagmus [4]. Lesions within the long ascending sensory tracts can cause impaired proprioception and vibration sense [4]. Muscle weakness and spasticity compromise the ability to maintain balance [6]. Because of the frequent involvement of these components in MS, patients suffer from balance disorders and consequently higher risk of falls $[2-4,7]$.

The aim of the present pilot study was to evaluate the balance control in a group of MS patients using clinical tests and posturographic methods in different sensory conditions and during cognitive task execution.

\section{Material and methods}

\section{Subjects}

Sixty-two subjects were included in the investigation. Thirty-two patients with MS were recruited from the Department of Neurology in Zabrze, Silesian University of Medicine in Katowice and its adjacent outpatient clinic. Thirty control subjects matched for age, gender, nianych testach. Deficyt stabilności powiększa się w odpowiedzi na utrudnianie warunków badania. Zwiększenie ryzyka upadków wiąże się ze zwiększeniem prędkości i długości swobodnych wychwiań postawy, a związek ten jest najsilniej wyrażony w płaszczyźnie czołowej.

Słowa kluczowe: stwardnienie rozsiane, stabilność postawy, zadanie arytmetyczne, warunki sensoryczne.

and body mass index (BMI) were recruited from various sources of convenience.

The MS group involved patients with a diagnosis of MS made in accordance with McDonald's criteria [8]. Patient's disability was determined using Kurtzke Expanded Disability Status Scale (EDSS) [9,10]. To be included in the study, a subject had to be able to stand unassisted without any devices for at least 60 seconds. Subjects were not included if they exhibited dysfunctions affecting balance or musculoskeletal disorders limiting locomotion or balance, or if they received drugs with a known association with increased risk of falls. The other exclusion criteria included severe pain, nystagmus or vertigo reported on the day of evaluation, cognitive and aphasic disorders which could produce difficulties with understanding of instructions, and alcohol abuse in the past history. According to the clinical examination, none of the patients presented symptoms of the fatigue syndrome or depression. Because of lowered mood, three persons were treated with antidepressants.

The control group consisted of 30 gender- and agematched healthy subjects. Volunteers were recruited to the study according to the same exclusion criteria.

Clinical characteristics of the group are presented in Table 1.

The research was accepted by the Senate Ethics Committee of the Medical University of Silesia in Katowice. Prior to testing, the purpose of the study was explained to the subjects and informed consent was obtained.

\section{Methods}

MS patients were evaluated using the EDSS. All subjects participating in the study were investigated using Balance Performance Oriented Mobility Assessment (BPOMA) [11-13]. This test was prepared to evaluate postural balance, and was dedicated primarily for the elderly. The advantage of this test is $85 \%$ 
compatibility between the results of test made by different researchers and high sensitivity (about 93\%) in evaluation of risk of falls [14]. The posturographic part of the study involved the Sensory Organisation Test (SOT) and Clinical Test of Sensory Interaction and Balance (CTSIB) $[15,16]$.

Postural sway (excursions of the centre of foot pressure - COP) were measured by the stabilometric platform Emildue (CosmoGamma, Italy) and all posturographic data were collected by a Pentium-class personal computer with a sampling frequency of $100 \mathrm{~Hz}$. Localization of COP in static conditions is compatible with COG (centre of gravity). This compatibility is estimated at about $97 \%$, and diminishes in dynamic conditions $[17,18]$.

Subjects were asked to stand barefoot on the force platform with feet abducted by $30^{\circ}$, heels separated by $2 \mathrm{~cm}$ and arms resting at their sides. Subjects were barefoot to minimize possible variability in performance due to differences in footwear. During testing with the eyes open subjects looked at a fixation point located on the wall in front of them at the distance of $2 \mathrm{~m}$. The quiet stance data were acquired during 50 -second tests with open and closed eyes on a stable (T1) and unstable (T2) surface, as well as with eyes open on a stable surface while executing a simple arithmetic task, i.e. counting aloud from 100 to 0 (T3) [16,19-21]. We evaluated sway velocity, mediolateral sway length and anteroposterior sway length. The unstable surface was obtained using a $10 \mathrm{~cm}$ thick layer of plastic foam, placed on top of a force platform $[21,22]$. In this way, interference with proprioceptive information derived from the feet and ankles is obtained, which makes the test more sensitive to disturbances of information coming from the vestibular system. On the other hand, testing on the stable surface with non-limited visual conditions involves the balance control system utilizing signals predominantly from the visual system [23]. The following variables were measured: mean sway in the coronary and sagittal plane, and sway velocity. The room temperature during all tests was $22^{\circ} \mathrm{C}$.

Statistical analysis was performed with Statistica (StatSoft, Inc.) v. 8.0 software, using nonparametric Mann-Whitney U-test or Kruskal-Wallis test according to the number (kind) of comparisons. Associations between variables were determined using Spearman rank correlation tests. The significance level was set at $p<0.05$.
Table 1. Characteristics of the groups

\begin{tabular}{|llc|}
\hline & $\begin{array}{l}\text { Patients with } \\
\text { multiple sclerosis } \\
\mathbf{n = 3 2}\end{array}$ & $\begin{array}{c}\text { Control } \\
\text { group } \\
\mathbf{n = 3 0}\end{array}$ \\
\hline Sex & & \\
\hline female & 22 & 20 \\
\hline male & 10 & 10 \\
\hline Age, years (mean \pm SD) & $33.5 \pm 10.61$ & $28 \pm 9.9$ \\
\hline $\begin{array}{l}\text { Body mass index, } \\
\text { mean } \pm \text { SD (range) }\end{array}$ & $25.25 \pm 4.35$ & $25.27 \pm 0.5$ \\
\hline $\begin{array}{l}\text { Disease duration, } \\
\text { years (mean } \pm \text { SD) }\end{array}$ & $3.28 \pm 3.25$ & $(19.31-38.71)$ \\
\hline $\begin{array}{l}\text { EDSS score, } \\
\text { mean } \pm \text { SD (range) }\end{array}$ & $2.42 \pm 1.07(1-4.5)$ & \\
\hline FS score, mean \pm SD (range) & \\
\hline pyramidal & $1.75 \pm 1.13(0-4)$ & \\
\hline vestibular/cerebellar & $0.5 \pm 0.76(0-2)$ \\
\hline somatosensory & $0.94 \pm 0.84(0-3)$ & \\
\hline
\end{tabular}

$S D$ - standard deviation, EDSS - Expanded Disability Status Scale, FS - functional scale

\section{Results}

Mean BPOMA score was $22.84 \pm 4.47$ points in the MS group and 28 points in the control group $(p<0.001$, Mann-Whitney U-test). We also found a negative correlation between EDSS and BPOMA scores $(R=-0.52, p=0.002)$.

In the MS group, sway velocity and mean mediolateral and anteroposterior sway in all tests were significantly greater than in controls. Progression of changes in response to increased difficulty of the test was also more pronounced in the MS group. Differences between groups were significant (Fig. 1).

Figures 2 and 3 illustrate the results of analysis of data using the Kruskal-Wallis test in MS and control groups. Change of sensory conditions and cognitive test execution during the trial increased the values of examined variables in MS patients. The most pronounced deficit of stability was found in the closed eyes test on an unstable surface. The results obtained in this test were significantly different than measurements performed in other tests. This analysis presented that deficit of visual information had a slightly stronger impact on postural control in MS patients. Also in the control group, there was an increase in values of measured parameters in response to change of sensory conditions and cognitive test execution during the trial; the most pronounced rise of all parameters' values was observed in a test limiting both visual and proprioceptive information. Analysis of results obtained in this group 
A

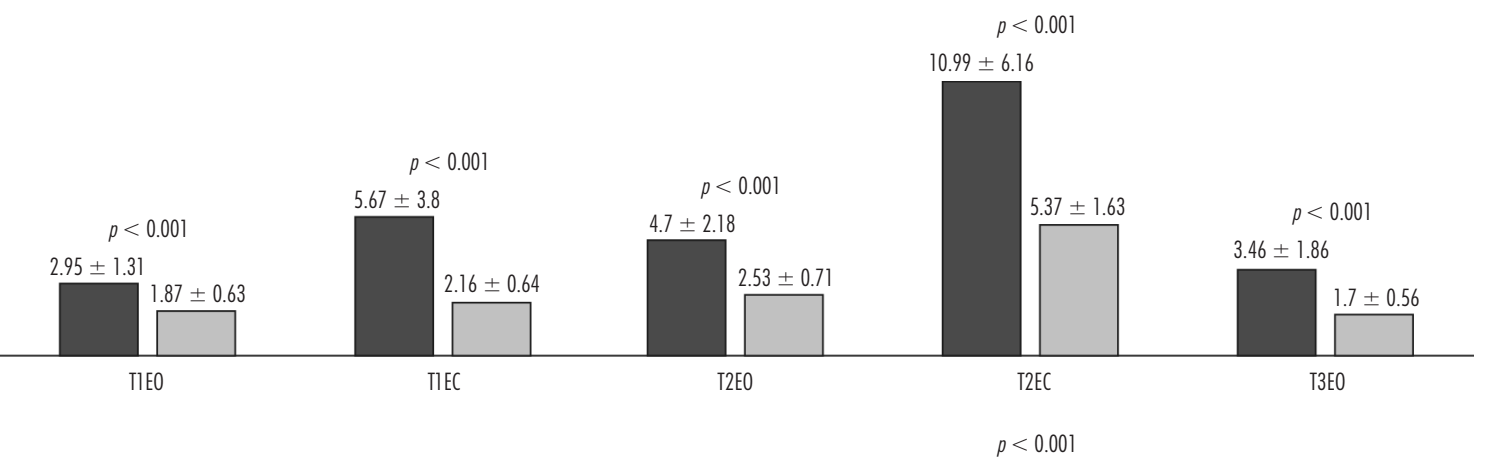

B

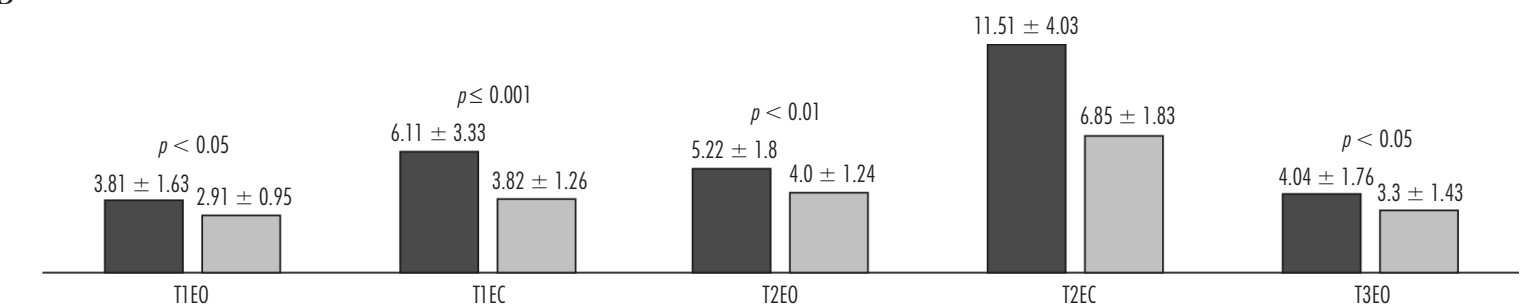

C

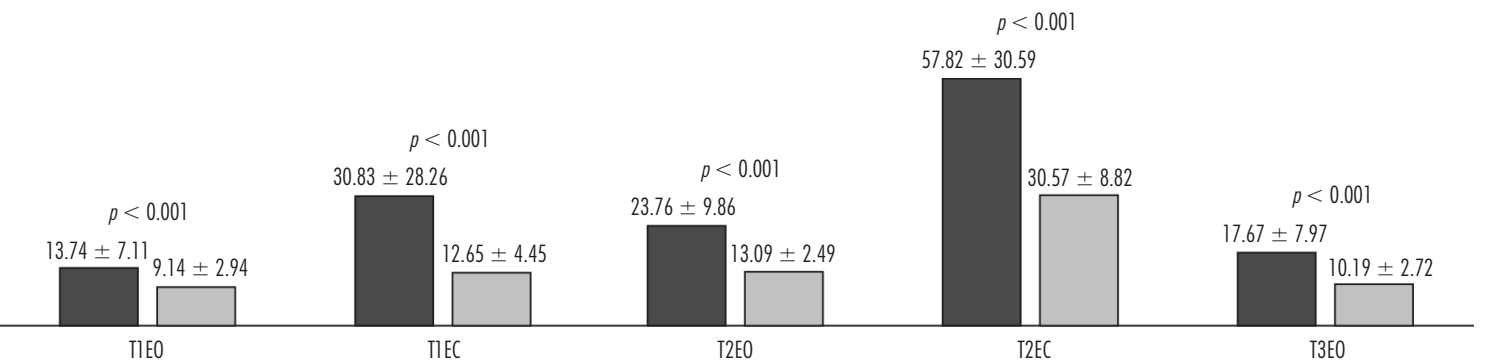

$T 1$ - tests on the stable surface, $T 2$ - tests on the unstable surface, EO - open eyes, EC - closed eyes, T3 - test on the stable surface with eyes open on a stable surface while executing a simple arithmetic task

Fig. 1. Comparison between patients with multiple sclerosis (dark colour) and control group (bright colour); A - mediolateral sway length ( \pm standard deviation [SD]); $B$ - anteroposterior sway length $( \pm S D) ; C$ - mean sway velocity $( \pm S D)$ ( $p$-values for differences in Mann-Whitney U-test)

points to similar input of sensory information of both modalities on postural balance control.

According to the results of the BPOMA test, we divided the MS group into two subgroups: with low and high risk of falls. Eighteen subjects with BPOMA score of 24-28 points were classified as a subgroup at low risk of falls and 14 patients who scored 12-23 points were recognized as a subgroup with high risk of falls. In the subgroup with high risk of falls, greater values of estimated parameters were observed in comparison with the low risk of falls subgroup. These differences were especially distinct for sway velocity and anteroposterior sway, as was demonstrated by Mann-Whitney U-test and Spearman's correlation tests. The detailed results are shown in Table 2.

\section{Discussion}

This study shows that patients with MS have postural balance deficit revealed in clinical examination using Balance Performance Oriented Mobility Assessment according to Tinetti. This method differentiated patients from controls and may be used for evaluation of balance deficit and for assessment of the risk of falls.

Postural balance assessment using clinical tests in patients with MS was performed by Frzovic et al. They demonstrated significantly worse postural stability control in the MS group. Differences between patients and healthy controls in static tests were most pronounced in trials with a restricted lateral plane of support; "enhanced" Romberg test and single leg test. 
A

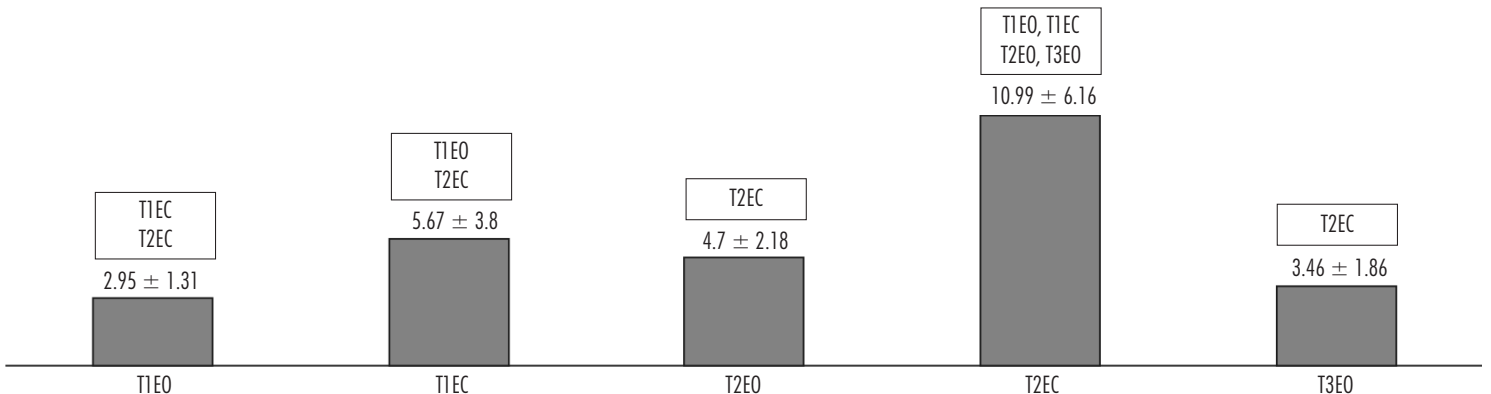

B

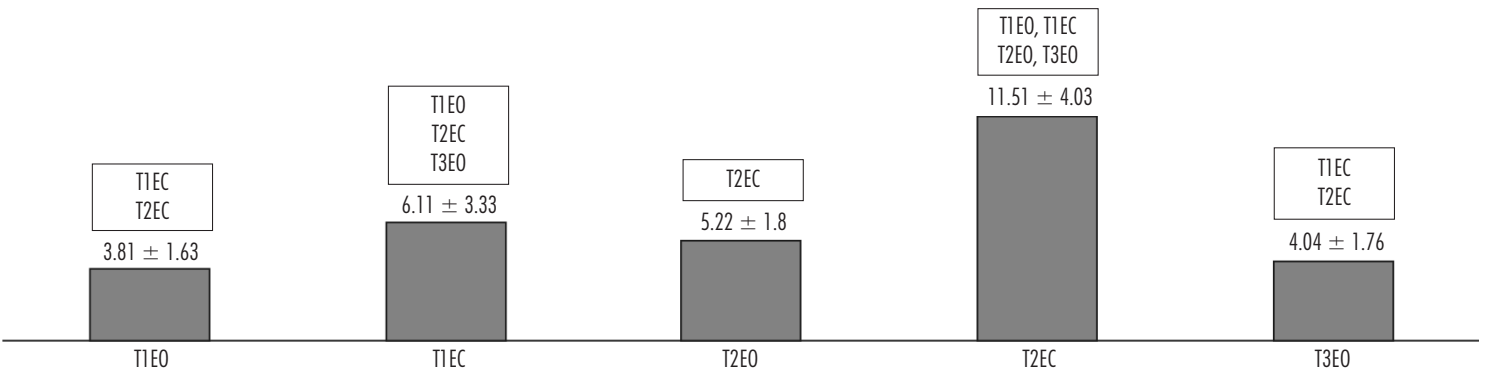

C

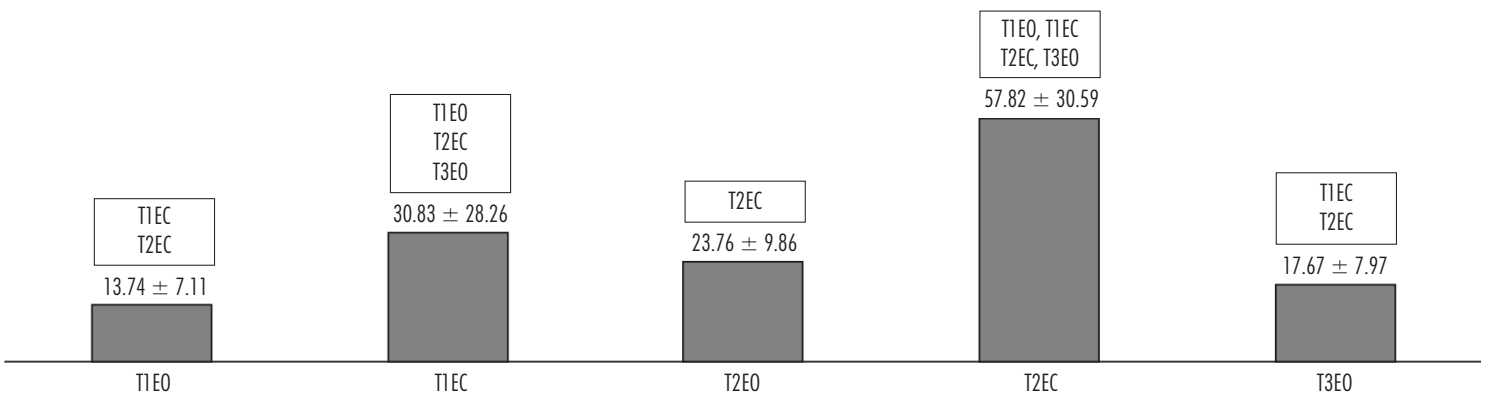

$T 1$ - tests on the stable surface, $T 2$ - tests on the unstable surface, EO - open eyes, EC - closed eyes, T3 - test on the stable surface with eyes open on a stable surface while executing a simple arithmetic task

Fig. 2. Results in patients with multiple sclerosis; $A$ - mediolateral sway length ( \pm standard deviation [SD]); B - anteroposterior sway length ( \pm SD), $C-$ mean sway velocity ( \pm SD) (abbreviations in boxes denote tests with results significantly different from those presented below the respective box [Kruskal-Wallis test])

In tests with a widened plane of support (feet parallel to each other and one foot before the other), no statistically significant differences were found. However, the position with feet one after the other at a distance of $10 \mathrm{~cm}$ brought some difficulties to some patients and resulted in premature finishing of the test. These authors proved the utility of dynamic tests using the patient's own movement as a destabilizing factor and an external force throwing the subject off balance in evaluation of balance control [2]. Soyuer et al. assessed clinical postural instability in three forms of MS - relapsingremitting, primarily progressive and secondarily progressive - and observed disturbances of static and dynamic balance in the examined group. They recommended static tests with reduced supporting plane, dynamic tests with patient's movement as a factor destabilizing posture, and the Walking Assessment Test according to Tinetti as useful in the assessment of balance control system lesion in MS and discriminating healthy subjects and patients [24].

In our study, we demonstrated marked differences in posturographic characteristics between patients with MS and healthy controls. Increased length of sway in both examined planes and sway velocity indicate considerable dysfunction of the balance control system. Abnormalities of particular parameters are indicative of disturbances in all stages of balance control. Both collection and afferent transition of sensory data, their 
A

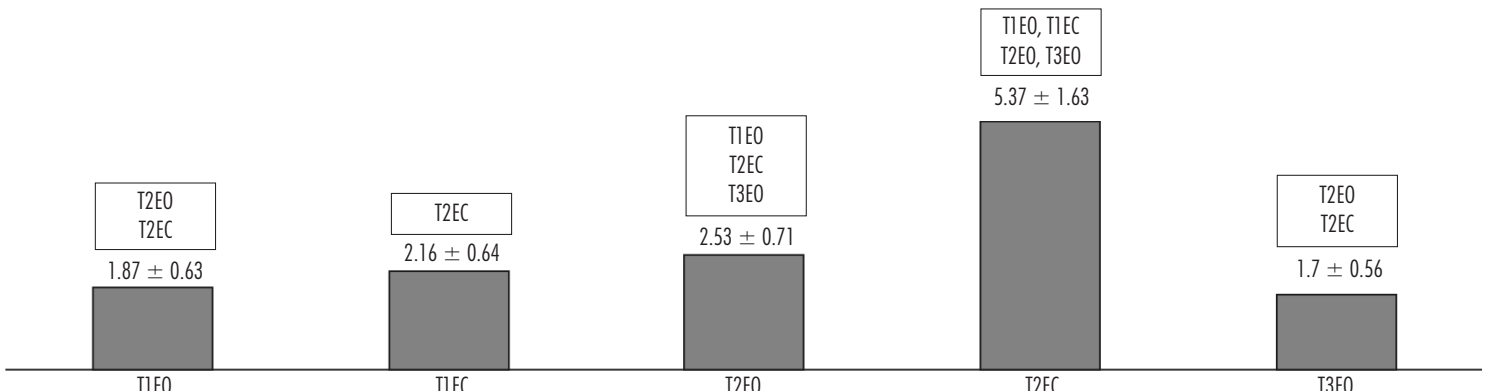

B

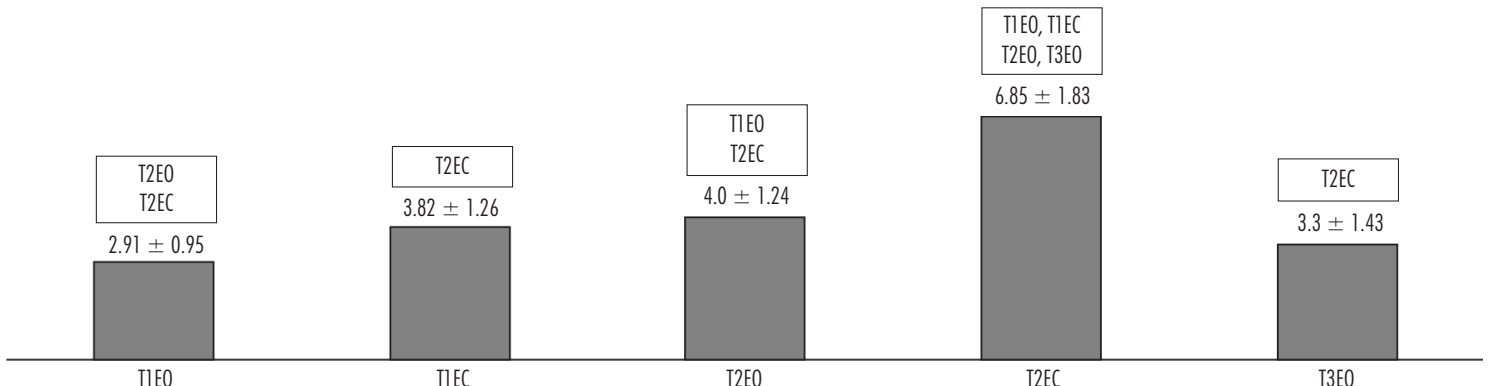

$\mathrm{C}$

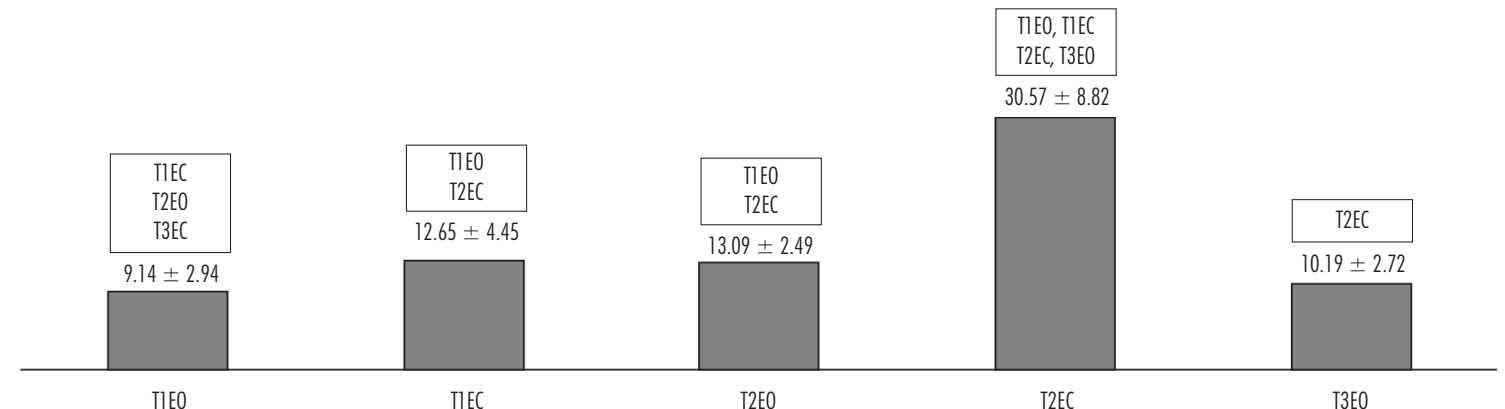

$T 1$ - tests on the stable surface, T2 - tests on the unstable surface, EO - open eyes, EC - closed eyes, T3 - test on the stable surface with eyes open on a stable surface while executing a simple arithmetic task

Fig. 3. Results in the control group; $A$ - mediolateral sway length ( \pm standard deviation $[S D]$ ); $B$ - anteroposterior sway length $( \pm S D), C-$ mean sway velocity $( \pm S D)$ (abbreviations in boxes denote tests with results significantly different from those presented below the respective box [Kruskal-Wallis test])

analysis and regulation of effectors resulting from it related to "dissemination" of the pathological process typical for MS. Our conclusion about postural instability in MS is consistent with other reports evaluating clinically and/or posturographically postural balance in this group of patients $[2,23,25,26]$.

Rougier et al. showed worsening of function of postural balance control in patients with MS, demonstrated as significant increase of all analysed posturographic parameters, i.e. sway velocity, area of sway and sway amplitude in coronary and sagittal planes. These authors formulated a hypothesis of "hasty" strategy of postural control used by MS patients. Duration of initiation of postural reaction (consisting of the time of conduction and motor planning) in the examined groups, patients with MS and healthy controls, was similar. In the light of research demonstrating that central transmission in MS is delayed, one can assume that compensation of reaction latency may be obtained by shortening of the time of motor planning. This results in less precise sway control of the centre of pressure and "untidy" structure of the posturogram [25]. Defects of the postural balance control system were also demonstrated in the study by Grigorova et al. They focused mainly on its sensory part and observed pronounced changes of posturogram characteristics, assessed on the basis of postural sway velocity in patients with MS compared to the control 
Table 2. Comparison between subgroups of multiple sclerosis patients with high and low risk of falls ( $p$-values for differences in Mann-Whitney U-test, and Spearman correlation coefficients $[R]$, and their respective $p$-values $[p])$

\begin{tabular}{|c|c|c|c|c|c|c|c|c|}
\hline & & \multicolumn{2}{|c|}{ High risk of falls } & \multicolumn{2}{|c|}{ Low risk of falls } & \multirow{2}{*}{$\begin{array}{c}\text { Mann-Whitney U-test } \\
p\end{array}$} & \multicolumn{2}{|c|}{ Spearman correlation } \\
\hline & & mean & $\pm S D$ & mean & $\pm S D$ & & $R$ & $p$ \\
\hline \multirow[t]{5}{*}{ Mediolateral sway } & T1EO & 3.62 & 1.25 & 2.43 & 1.12 & $p \leq 0.01$ & -0.53 & $p \leq 0.01$ \\
\hline & T1EC & 8.24 & 3.71 & 3.67 & 2.47 & $p \leq 0.001$ & -0.78 & $p \leq 0.001$ \\
\hline & $\mathrm{T} 2 \mathrm{EO}$ & 5.19 & 1.30 & 4.32 & 2.65 & $p \leq 0.05$ & -0.52 & $p \leq 0.01$ \\
\hline & T2EC & 13.36 & 9.17 & 9.80 & 3.73 & - & -0.27 & - \\
\hline & $\mathrm{T} 3 \mathrm{EO}$ & 4.07 & 1.90 & 2.98 & 1.74 & $p \leq 0.05$ & -0.53 & $p \leq 0.01$ \\
\hline \multirow{5}{*}{$\begin{array}{l}\text { Anteroposterior } \\
\text { sway }\end{array}$} & T1EO & 4.08 & 1.42 & 3.59 & 1.79 & - & -0.27 & - \\
\hline & T1EC & 8.15 & 3.63 & 4.52 & 1.99 & $p \leq 0.001$ & -0.66 & $p \leq 0.001$ \\
\hline & $\mathrm{T} 2 \mathrm{EO}$ & 5.76 & 2.12 & 4.81 & 1.44 & - & -0.32 & - \\
\hline & T2EC & 12.59 & 4.61 & 10.97 & 3.73 & - & -0.28 & - \\
\hline & T3EO & 4.36 & 1.16 & 3.79 & 2.11 & - & -0.40 & $p \leq 0.05$ \\
\hline \multirow[t]{5}{*}{ Main sway velocity } & T1EO & 17.50 & 8.98 & 10.81 & 3.12 & $p \leq 0.01$ & -0.59 & $p \leq 0.001$ \\
\hline & T1EC & 47.85 & 35.73 & 17.60 & 7.45 & $p \leq 0.001$ & -0.72 & $p \leq 0.001$ \\
\hline & $\mathrm{T} 2 \mathrm{EO}$ & 28.38 & 11.46 & 20.16 & 6.76 & $p \leq 0.05$ & -0.43 & $p \leq 0.05$ \\
\hline & $\mathrm{T} 2 \mathrm{EC}$ & 73.03 & 40.00 & 50.22 & 22.25 & - & -0.50 & $p \leq 0.01$ \\
\hline & T3EO & 21.88 & 9.12 & 14.39 & 5.11 & $p \leq 0.01$ & -0.49 & $p \leq 0.01$ \\
\hline
\end{tabular}

$T 1$ - tests on the stable surface, $T 2$ - tests on the unstable surface, EO - open eyes, EC - closed eyes, T3 - test on the stable surface with eyes open on a stable surface while executing a simple arithmetic task

group. Defects increased with the limitation of visual and proprioceptive information [23]. Examined patients were not able to perform a closed eyes test on an unstable surface, which points to severe pathology also in the vestibular system. These results showed that also the sensory part of the postural balance control system is disturbed in all modalities of relevant sensors. This study supports the hypothesis that vision and proprioception are almost of equal importance for postural adjustments. Jackson et al. also observed delayed afferent transmission of somatosensory signals from the lower extremities in spinal cord pathways of MS patients. These authors conclude that postural balance deficit results from disturbed visual, vestibular and somatosensory integration [3].

In the study by Rougier et al. patients with disturbed sensation of vibration in the lower extremities exhibited deterioration of postural stability demonstrated by increase of stabilogram area, mean velocity and amplitude of postural sway in the coronary and sagittal plane [25].

Increased risk of falls has been proved in patients with MS [7], and this tendency was confirmed by us in Tinetti's Walking and Posture Assessment Test. Results of posturographic assessment revealing elongation and acceleration of postural sway are consistent with clinical evaluation of the risk of falls.
These abnormalities are global and it is impossible to determine the plane in which they are the most intense. Our results suggest that the tests with concomitant visual and somatosensory information deficit are less useful. Melzer et al. also observed a tendency for increase of stabilogram parameter values in healthy elderly subjects with positive and negative history of falls. Medial-lateral sway and lateral instability ratio are the most useful predictors of increased risk of falls in their opinion [27].

Our results are consistent with data from the literature and suggest that disturbances of balance control in MS result from disseminated lesions in the central nervous system causing functional deficits at all stages of postural stability control due to the accumulation of small-scale damage [7].

\section{Conclusions}

1. Postural balance in patients with MS in clinical and posturographic assessment is significantly worse than in healthy controls.

2. Postural stability deficit is enhanced in response to more difficult testing conditions.

3. Increased risk of falls is related to the increased postural sway velocity and length of mean sway; this association is most pronounced in the coronary plane. 


\section{Disclosure}

Authors report no conflict of interest.

\section{References}

1. Wiles C.M., Newcombe R.G., Fuller K.J., et al. Controlled randomized crossover trial of the effect of physiotherapy on mobility in multiple sclerosis. J Neurol Neurosurg Psychiatr 2001; 70: 174-179.

2. Frzovic D., Morris M.E., Vowels L. Clinical tests of standing balance: performance of persons with multiple sclerosis. Arch Phys Med Rehabil 2000; 81: 215-221.

3. Jackson R.T., Epstein C.M., De l'Aune W.R. Abnormalities in posturography and estimations of visual vertical and horizontal in multiple sclerosis. Am J Otol 1995; 16: 88-93.

4. Nelson S., Di Fabio R., Anderson J. Vestibular and sensory interaction deficits assessed by dynamic platform posturography in patients with multiple sclerosis. Ann Otol Rhinol Laryngol 1995; 104: 62-68.

5. Kraft A., Wessman H. Pathology and etiology in multiple sclerosis. Phys Ther 1974; 54: 716-720.

6. Ashburn A., De Souza L. An approach to the management of multiple sclerosis. Physiother 1988; 4: 139-145.

7. Cattaneo D., De Nuzzo C., Fascia T. Risk of falls in subjects with multiple sclerosis. Arch Phys Med Rehabil 2002; 83: 864-867.

8. McDonald W.I., Compston A., Edan G., et al. Recommended diagnostic criteria for multiple sclerosis: guidelines from the international panel on the diagnosis of multiple sclerosis. Ann Neurol 2001; 50: 121-127.

9. Kurtzke J.F. A poroposal for uniform minima record of disability in multiple sclerosis. Acta Neurol Scand 1981; 64: 110-129.

10. Kurtzke J.F. Rating neurologic impairment in multiple sclerosis: an expanded disability status scale (EDSS). Neurology 1983; 33: 1444-1452.

11. Tinetti M.E., Williams T.F., Mayewski R. Fall risk index for elderly patients basic on number of chronic disabilities. Am J Med 1986; 80: 429-434.

12. Raiche M., Herbert R., Corriveau H. Screening older adults at risk of falling with the Tinetti balance scale. Lancet 2000; 356: 1001-1002.

13. Corriveau H., Hébert R., Raiche M., et al. Evaluation of postural stability in the elderly with stroke. Arch Phys Med Rehabil 2004; 85: 1095-1101.

14. Błaszczyk J.W. Kliniczne testy oceny stabilności postawy. In: Błaszczyk J.W. Biomechanika kliniczna. $1^{\text {st }}$ ed. PZWL, Warszawa 2004, pp. 219-221.

15. Horak F.B. Clinical measurement of postural control in adults. Physical Ther 1987; 67: 1881-1885.

16. Shumway-Cook A., Horak F.B. Assessing influence of sensory interaction on balance: suggestion from the field. Physical Ther 1986; 66: 1548-1550.

17. Jian Y., Winter D.A., Ischac M.G., et al. Trajectory of the body $\mathrm{COG}$ and $\mathrm{COP}$ turning initiation and termination of gait. Gait Posture 1993; 1: 9-22.

18. Chang H.A., Krebs D.E. Dynamic balance control in elders: gait initiation assessment as a screening tool. Arch Phys Med Rehabil 1999; 80: 490-494.
19. Marchese R., Bove M., Abbruzzese G. Effect of cognitive and motor tasks on postural stability in Parkinson's disease: a posturographic study. Mov Disord 2003; 18: 652-658.

20. Marigold D.S., Eng J.J. The relationship of asymmetric weightbearing with postural sway and visual reliance in stroke. Gait Posture 2006; 23: 249-255.

21. Raymakers J.A., Samson M.M., Verhaar H.J. The assessment of body sway and choice of the stability parameter(s). Gait Posture 2005; 21: 48-58.

22. Shumway-Cook A., Anson D., Haller S. Postural sway biofeedback: its effect on reestablishing stance stability in hemiplegic patients. Arch Phys Med Rehabil 1988; 69: 395-400.

23. Grigorova V., Ivanov I., Stambolieva K. Effect of sensory inputs alteration and central sensory disinteraction on postural sway and optokinetic reflex maintaining simultaneously body balance. Acta Physiol Pharmacol Bulg 2001; 26: 177-180.

24. Soyuer F., Mirza M., Erkrkmaz U. Balance performance in three forms of multiple sclerosis. Neurol Res 2006; 28: 555-562.

25. Rougier P., Faucher M., Cantalloube S., et al. How proprioceptive impairments affect quiet standing in patients with multiple sclerosis. Somatosens Mot Res 2007; 24: 41-51.

26. Martin C.L., Phillips B.A., Kilpatrick T.J., et al. Gait and balance impairment in early multiple sclerosis in the absence of clinical disability. Mult Scler 2006; 12: 620-628.

27. Melzer I., Benjuya N., Kaplanski J. Postural stability in the elderly: a comparison between fallers and non-fallers. Age Ageing 2004; 33: 602-607. 